\title{
Regional Foreign Direct Investment and Wage Spillovers: Plant Level Evidence from the U.K Electronics Industry*
}

Nigel Driffield and Sourafel Girma

Birmingham University

University of Leicester

\section{Introduction}

The impact of foreign direct investment (FDI) on host economies has been of interest for many years, and many of the perceived benefits or detrimental effects of FDI in this context can be traced back to Dunning (1958). Of particular interest, with the increased scale and scope of FDI and the rate of increase in the speed of "globalisation" has been the extent to which this had contributed to increased inequality, both between and within locations and groups of individuals. The impacts of globalisation on host country labour markets have become increasingly important to both academics and policy makers, as the attraction of internationally mobile capital has become a (if not the) major function of regional development agencies across Europe and North America.

Early studies on the labour market impacts of FDI were essentially confined to determining the total employment gain from FDI and relating new employment gains to the size of subsidies provided to attract the investment. However, more recently both policy makers and academics have become concerned with the wider impacts of FDI on host country labour markets, see for example Driffield and Taylor (2000). While it is generally accepted that at least under certain conditions, productivity spillovers do occur from foreign

\footnotetext{
* Thanks are due to the ONS Business Data Linking Project for providing access to the ARD database. Financial support from the Leverhulme Trust (Programme Grant F114/BF) and the European Commission Fifth Framework Programme (Contract No. HPSE-CT-1999-00017) is gratefully acknowledged. We also like to thank the Editor and an anonymous referee from whose comments the paper has greatly benefited.
} 
to domestic firms within the $\mathrm{UK}^{1}$, it is less clear that such spillovers benefit those for whom subsidies are designed, unskilled workers and workers in areas of above-average unemployment.

This paper focuses the impact of regional FDI on both skilled and unskilled workers wages within the UK electronics industry. The UK electronics industry is the fifth largest in the world in terms of sales employing over 400,000 people in manufacturing with an additional 100,000 in related services and software ${ }^{2}$. It is an industry with an extremely high level of multinational activity. In 1996 over 25\% of the stock of inward investment in the UK from the US, Japan and the rest of the EU were in electrical engineering and electronics, having increased from $19 \%$ in 1987. Japanese investment is particularly concentrated in this sector, accounting for over $50 \%$ all Japanese investment in the U.K. Multinational firms undertake a significant proportion of the innovative activity in the sector. Cantwell and Iammarino (2000) indicate that in semiconductors the share of foreign-owned firms in total patents was over $60 \%$ for the UK as a whole, and $75 \%$ for the South East in particular. High levels of Regional Selective Assistance have gone to firms in this sector. For the period 1991$199472 \%$ of regional assistance in electrical engineering went to foreign-owned firms in the UK, well above the national average of 40\% (Taylor and Wren, 1997).

The purpose of this paper is then to test the impact that inward investment in the UK has on workers in domestically owned establishments. Wage spillovers from FDI are found to be not as large, or as prevalent as productivity spillovers, based on previous work. Wage spillovers are largely confined to skilled, rather than unskilled workers, implying that the benefits of FDI are unevenly distributed. There are numerous explanations of this. Firstly, skilled workers are expected to benefit from an increased demand for labour, as the imported technology is complementary with skilled labour. The imported technology is likely therefore

\footnotetext{
${ }^{1}$ See for example Blomström et al (2001), Girma and Wakelin (2001), Driffield (1999), Driffield (2001).
} 
to increase productivity of this complementary labour, and in turn generate higher wages. Further, Barrell and Pain (1997), show that the technology accompanying FDI is unskilledlabour augmenting, reducing the demand for unskilled labour, and therefore relative wages of unskilled workers. This follows the arguments of Machin and Van Reenen (1998), who demonstrate that new technology is complementary to skilled labour, and its introduction results in increased demand for skilled workers. Equally, it is anticipated that there may be causes of friction in terms of wage spillovers, particularly between the foreign and domestic sector. Labour market segmentation is an important phenomenon, particularly when considering mobility between domestic and foreign firms, see for example Driffield and Taylor (2000). As such, there is no guarantee that workers in domestic firms will be able to obtain jobs in foreign firms, with different skill requirements. Equally, a large proportion of inward investment in the UK is located in areas of high unemployment, so wage increases as a result of labour demand increases are perhaps unlikely. There are further factors likely to limit wage spillovers, particularly for unskilled workers, such as immobility, skill transferability and changes in factor demand, and these are discussed in more detail in the following sections.

The paper is set out as follows: section 2 discusses previous work on FDI and wage spillovers, while section 3 presents the empirical model that is employed. Data details are given in section 4 and the empirical findings are discussed in section 5 . Finally section 6 concludes.

\section{Previous work on FDI and factor demand.}

There are a number of studies that identify substantial differences in factor demand between foreign and domestic firms. The inference here is that foreign multinationals

\footnotetext{
${ }^{2}$ Source: Office of National Statistics.
} 
demonstrate higher levels of labour productivity, and in turn greater demand for high quality labour. Entry by such firms therefore is expected to impact on domestic labour markets via two mechanisms. Firstly, inward investment generates a straightforward labour demand effect, stemming from an exogenous increase in output. This is likely to be particularly important at the region and industry level rather than in the aggregate. While previous evidence suggests that this is likely to favour skilled, rather than unskilled workers, this will of course depend on the nature of the activities undertaken by the inward investors. Secondly, linked to this is the likely impact on domestic firms of the inflow of new technology that is assumed to accompany FDI. There is growing evidence for this in the UK - Driffield (1996) finds that foreign firms will pay wages above the industry average of around $7 \%$, partly due to productivity differences and Girma et al. (2001) report a wage and productivity differentials of 5\%. Conyon et al. (2002) find a wage differential of 3.4\% wholly attributable to productivity resulting from foreign acquisitions of indigenous firms. This foreign wage differential may therefore also act on the supply of labour to the domestic sector, as workers observe higher wages on offer elsewhere.

There is significant evidence that wage spillovers in general do occur, see for example Manning (1994). Moreover, Latreille and Manning (2000) evaluate inter-industry and interoccupational impacts, again finding that wages elsewhere impact on wage determination. It is therefore anticipated that entry by foreign firms, paying on average higher wages, will generate spillovers causing wages in the domestic sector to be bid up. Reasons for this are discussed in detail in Driffield (1996). However wage spillovers may be limited, either by activity, region, or occupational group. It is well established that a good deal of segmentation exists in the UK labour market, see for example McNabb and Whitfield (1998). In addition, it is well understood that unskilled workers are less mobile than skilled ones, and so interregional effects are likely to be smaller for unskilled workers than for skilled workers 
(McCormick, 1997). Linked to the segmentation literature is the evidence that technological change generates an increase in wage inequality, see for example Machin and Van Reenen (1998), by increasing the relative demand for skilled workers. Further, Barrell and Pain (1997) and Girma et al (2001) demonstrate that productivity spillovers from FDI are partly facilitated by domestic firms becoming more skill intensive. This discussion suggests that wage spillovers will be greater for skilled workers than for unskilled workers, in terms of both inter-regional impacts, and foreign to domestic impacts. In addition Blomström et al (2001) show that spillovers from FDI accrue only where domestic firms are in a position to assimilate the potential externality, through a certain level of technical competence. As such therefore, one would expect such gains to occur in the more technologically advanced regions of the UK, with the same being said for labour market effects. Further discussion of these possibilities is found in Driffield and Taylor (2000). This is an important issue for policy makers, as concern has been expressed that both skill shortages and labour market tightening have been exacerbated in certain parts of the country by inward investment.

\section{Empirical model of wages spillovers from the regional FDI}

Our modelling approach is based upon a simple structural model of the labour market highlighting the role of alternative domestic and foreign wages as comparison incomes impacting on labour supply. The literature concerning the labour market impact of FDI suggests that there are two important effects. Firstly, there is the direct effect that inward investment is expected to have on wages through labour market impacts. There may also be an additional secondary effect, as productivity spillovers from FDI increase productivity and increase labour demand within the domestic sector. In addition, it is well documented that foreign firms pay higher wages than domestic firms, and this may act to reduce the supply of labour at a given wage rate, and thus act to increase wages. 
To characterise these effects we assume a Cobb-Douglas production function for the domestic sector, of the form $Q=A K^{\alpha} L^{\beta}$, where $Q$ is output, $K$ is capital and labour $L$ is split into skilled and unskilled.. A denotes total factor productivity (TFP), which in the presence of spillovers will be influenced by external investment. In domestic firms for example, it is likely to be determined in part by the level of foreign capital. Writing the marginal revenue product of labour as $M P_{L}=\partial Q / \partial L=A K^{\alpha} \beta L^{\beta-1}$, at equilibrium wages are given by:

$$
W=p A K^{\alpha} \beta L^{\beta-1}
$$

where $p$ represents the market price of the good produced.

However, it is also necessary to introduce the supply side of the labour market $L=L(W, \bar{W})$, where $\mathrm{W}$ represents the wage on offer, and $\bar{W}$ represents the vector of alternative wages available. This will include wages available to skilled and unskilled workers, wages available in other industries, and wages available in other regions. In addition, for the reasons discussed about, wages paid by foreign and domestic firms may have different impacts. Our data, discussed below, has an industry, region, and time component, so the vector of external wage rates $\bar{W}$ encompasses the following terms:

Same industry and region domestic (foreign) wage $W_{1}^{d}\left(W_{1}^{f}\right)$ defined as the average wage of all other domestic (foreign) plants inside the same region and the same four-digit industry:

- Same industry and outside region domestic (foreign) wage $W_{2}^{d}\left(W_{2}^{f}\right)$ : defined as the distance-weighed average wage of domestic (foreign) plants outside the same region and but inside four-digit industry:

- Same region but outside own industry domestic (foreign) wage $W_{3}^{d}\left(W_{3}^{f}\right)$ : defined as the average wage of domestic (foreign) plants in the same region and the same two-digit industry , excluding the plant’s own four-digit sector: 
As such therefore, the reduced form wage equation can be written as:

$$
\ln (W)=\phi_{0}+\phi_{1} \ln (T F P)+\phi_{2} \ln (K)+\sum_{k=l, d} \sum_{j=1}^{3} \phi_{k j} \ln \left(W_{j}^{k}\right)+\varepsilon
$$

We also postulate that regions with high levels of unemployment, and low skill levels, may respond differently from other regions. We capture this by distinguishing between assisted and non-assisted area status. Regions with assisted area (AA) status characteristically suffer from a lack of skilled workforce, and so we interact all outside wages variables with an AA with dummy in order to explore whether the forces that generate inter-regional wage spillovers act to differing extents across assisted and non-assisted areas.

In our empirical specification we extend equation (2) in several directions. First, we exploit the panel nature of our data and incorporate individual effects $\left(f_{i}\right)$ into the model to control for unobserved time-invariant heterogeneity factors that affect wages. Such factors include firm-specific human capital attributes, working conditions and managerial ability. The impact of regional or four-digit industry dummies is also subsumed in the fixed effect. Third we include a cross wage elasticity term at plant level to explore if the wage growths of skilled and unskilled workers tend to move in the same direction. In addition a lagged wage variable is included. In standard wage determination models, see for example Stewart (1990), a vector of individual worker characteristics such as age, experience, education, gender and ethnic group would be included. Such data are clearly not available at this level of disaggregation, but by construction these effects are strongly correlated with the lagged dependent variable. Notice that total factor productivity not only captures efficiency effects, but also rent sharing, in the manner postulated by Stewart (1990). Price data are not available here, so price differences are captured, partly by the TFP term, but also by the industry effects. Finally, we use time $\left(f_{t}\right)$ dummies to control for other economy-wide factors affecting wage settlements. 
Plant level total factor productivity is estimated using the semiparametric approach developed by Olley and Pakes (1996), which is outlined in Appendix A. The main advantage of this approach over more traditional production function estimation techniques is its ability to controls for both selection and endogeneity in a simultaneous fashion.

The final estimating wage equation for each type worker is:

$$
w_{i t}=\alpha_{1} w_{i t-1}+\beta X_{i t}+\sum_{j=1 k=d, f}^{3} \sum_{k j} w_{j}^{k}+\sum_{j=1 k=d, f}^{3} \sum_{k j}\left(\gamma_{j} w_{j}^{k} \times A_{i t}\right)+f_{i}+f_{t}+\varepsilon_{i t}
$$

where $w$ is either the log of skilled or unskilled wages of plant $i$ at time $t$; the $w^{k}$ represent the log of the various alternative wages as defined earlier. The regional element of this term may be interpreted as a spatial dependence term, but with less restriction on the coefficients than would normally be implied in the regional science literature, see for example see for example Anselin and Florax (1995), and Le Sage (1999). $A_{i t}$ is a dummy indicating whether the plant is located in government Assisted Areas, and the vector $\mathrm{X}$ consists of the log plant level capital , cross wage term and total factor productivity.

Equation (3) represents a dynamic panel data model of wages with plant-specific effects. The estimation problems of dynamic models from short panels is well documented in the econometric literature (see Baltagi, 1995 and references therein). The basic difficulty lies in the fact that the presence of fixed effects renders the lagged dependent variable correlated with the equation disturbance term. Standard "within” transformation typically used in static models fails to deliver consistent estimators. A popular way of circumventing this problem is to the remove the fixed effects via first-differencing and then employ a variant of the instrumental variable estimation technique (e.g. GMM). In this paper lagged wages, capital 
and productivity are employed as instruments in the first-differenced (i.e. wage growth) equations in the spirit of Anderson and Hsiao (1982) and Arellano and Bond (1991). ${ }^{3}$

However, a further issue here is that with 2 types of labour (skilled and unskilled) the estimation of (3) for these groups should allow for simultaneity in wage determination, something that is hitherto ignored in previous studies, see for example Latreille and Manning (2000), Lee and Pesaran, (1993). The first-differenced versions of the skilled and unskilled wages equations are therefore estimated simultaneously via iterated three stage least squares (FD-3SLS) using the same set of instruments described above (that is the instrument set suggested by single equation dynamic panel data procedures). Overidentification test statistics (which are the FD-3SLS objective function evaluated at the solution points and divided by the sample size) are also computed to test the validity of the instrumental variable candidates. To our knowledge this is the first paper that attempts to estimates a system of simultaneous dynamic wage equations. ${ }^{4}$

\section{Data details}

This paper draws on the Annual Respondents Database (ARD) to identify domestic and foreign plants in the UK electronics industry for the period 1980-92. The ARD is provided by the Office for National Statistics in the UK under controlled conditions, and it consists of establishment level data arising from the Annual Census of Production until 1997 and the Annual Business Inquiry thereafter. As Oulton (1997), Griffith (1999) and Barnes and Martin (2002) provide very useful introductions to the data set, we only include a brief discussion of some of the features of the data that are relevant to the present work.

\footnotetext{
${ }^{3}$ Our approach of estimating the system of dynamic panel equations is in the spirit of Holtz-Eakin et al (1988), using lagged values as instruments to generate orthogonality conditions on differenced data, and employing GMM.

${ }^{4}$ Notice that in the linear context we are working with, the 3SLS estimator can be derived as a GMM estimator from the orthogonality conditions implied by the set of instrument (see Theorem 5 in Cornwell et al , 1992)
} 
The ARD consists of two files for the relevant period. That known as the 'selected file', contains detailed information on a sample of establishments that are sent inquiry forms and respond or have their responses imputed. The second file comprises the 'non-selected' (non-sampled or non-response) establishments and only basic information such as employment, location, industry grouping and foreign ownership status is recorded. For our study period, data on some 14,000-19,000 establishments across all manufacturing are provided in the selected file for each year, based on a stratified sampling scheme. The scheme tends to vary from year to year, but establishments with more than 100 employees are always sampled. In the electronics industry, selected establishments account for less than one eighth of the total number of establishments, but for more than 80 percent of output and employment. In the ARD, an establishment is defined as the smallest unit that is deemed capable of providing information on the Census questionnaire. Thus a 'parent' establishment reports for more than one plant (or 'local unit' in the parlance of ARD). For selected multiplant establishments, we only have aggregate values for the constituent plants. Indicative information on the 'children' is available in the 'non-selected' file. In the sample period considered in this paper 95 percent of the establishments that are present in the electronics industry are single-plant firms ${ }^{5}$. In the actual sample we used for the econometric estimation this figure is around 80 percent. Thus most of the data we used is actually plant level data. Like the majority of researchers who have worked with the ARD (e.g. Disney et al. 2000; Griffith, 1999), we use data on multi-plant establishments. We define the electrical and electronic sector as the two two-digit classes 33 and 34 (using the SIC80 revision) spanning 17 four-digit sectors. The main advantage of using this type of data is that it removes a good deal of the heterogeneity that may be present in cross industry studies, particularly when attempting to impose uniform coefficients. In addition, it removes the inherent sample

\footnotetext{
${ }^{5}$ As a result we tend to use the terms plant and establishment interchangeably for what are termed
} 
selection problems that accompany treating FDI as an exogenous variable. It is now well understood that sectoral characteristics influence the investment decision by multinationals. For example FDI tends to be concentrated in more productive sectors, which also have above average wage rates. This implies that FDI might be endogenous to the process governing the dynamics of wages. The use of a narrowly defined industry group is likely to mitigate the impact of this potential endogeneity problem

The precise definition of the sub-sectors and the share of foreign ownership in that sector are given in Table 1. Foreign presence is measured both as the share of employment and as the number of establishments

Table 1:

Employment share of MNE activity in the Electronics Industry ${ }^{6}$

\begin{tabular}{|l|r|r|}
\hline \multicolumn{1}{|c|}{ Standard Industrial Classification (1980) } & 1980 & 1992 \\
\hline Office Machinery and Electronic data processing equipment (330) & 0.345 & .684 \\
\hline Insulate wires and cables (341) & 0.205 & .198 \\
\hline Basic electrical equipment (342) & .073 & .345 \\
\hline Electrical equipment for industrial use , and batteries and accumulators (343) & .124 & .175 \\
\hline $\begin{array}{l}\text { Telecommunication equipment, electrical measuring equipment, electronics } \\
\text { capital goods, passive electronic components (344) }\end{array}$ & .231 & .266 \\
\hline Other electrical and electronic engineering (345, 346,347) & .311 & .442 \\
\hline
\end{tabular}

Table 2 gives the employment share of foreign multinationals across ten regions for 1980 and 1992.

Table 2:

Pattern of regional FDI (employment share)

\begin{tabular}{lcc}
\hline Region & $\mathbf{1 9 8 0}$ & $\mathbf{1 9 9 2}$ \\
\hline East Anglia & 0.215 & 0.262 \\
East Midlands & 0.076 & 0.156 \\
North West* & 0.146 & 0.228 \\
Northern England* & 0.125 & 0.236 \\
\hline
\end{tabular}

establishments in the ARD.

${ }^{6}$ Industry- wide variables in the econometric analysis are calculated at four-digit industry level , encompassing 17 sub-sectors. The summary statistics reported in Table 1 are at a much aggregate level lest we violate the disclosure criteria set by the ONS. 


\begin{tabular}{lll}
\hline Scotland* & 0.163 & 0.277 \\
South East & 0.204 & 0.298 \\
South West & 0.103 & 0.170 \\
Wales* & 0.192 & 0.297 \\
West Midlands* & 0.090 & 0.213 \\
Yorks. \& Humber. & 0.089 & 0.155 \\
\hline
\end{tabular}

Note: Regions denoted by * contain Assisted Areas

A few points are worth noting:

- In 1992 the regions with the highest share of FOE employment are Wales and the South East with around 30\% of employment in foreign firms.

- All regions have experienced a rise in the share of foreign employment, with the share more than doubling in both the East and West Midlands (although the former still has one of the lowest shares at 16\%).

- It is clear from the table that while the foreign employment share has fallen slightly in a few sectors, most sectors have experienced a rise in foreign employment. For instance, electronic data processing equipment experienced a large rise in foreign employment from $30 \%$ to almost $70 \%$ in 1992 making it the second-highest share of foreign employment. Basic electrical equipment also experienced a five-fold increase.

- In 1980 office machinery had the highest proportion of MNE employment, by 1992, this sector was overtaken by electronic consumer goods with over $80 \%$ of employment in foreign firms (rising from just over 20\% in 1980). Office machinery and active components both have around 50\% foreign employment.

The debate concerning spillovers has hypothesised that foreign-owned firms exhibit higher productivity and wages than domestic firms. Higher productivity reflects their superior technology and management skills giving rise to the possibility of spillovers from them to domestic firms. By way of a preliminary analysis, we investigate whether this hypothesis is supported by the data, and Table 3 presents the results for robust regressions estimating the foreign-domestic differentials using a variety of indicators as the dependent variable. We also 
separate domestic establishments by whether they are located in government assisted areas or not. The base group is made up of domestic establishments in non-assisted areas, and the coefficients on the various dummy variables thus give the margin with respect to these establishments. As Table 3 shows, foreign-owned firms have significantly higher labour productivity, capital intensity, and proportion of skilled workers than domestic plants. The wage differential between domestic establishments is negligible, but plants in assisted areas have lower labour productivity (3.5\%), lower capital intensity (45\%) and a smaller proportion of skilled workers (5\%) compared to their domestic counterparts.

Table 3:

Some differentials (in \%) between foreign and domestic establishments

\begin{tabular}{|l|l|l|l|l|l|}
\hline & $\begin{array}{l}\text { Skilled } \\
\text { Wages }\end{array}$ & $\begin{array}{l}\text { Unskilled } \\
\text { Wages }\end{array}$ & $\begin{array}{l}\text { \% of } \\
\text { skilled } \\
\text { workers }\end{array}$ & $\begin{array}{l}\text { Capital } \\
\text { intensit } \\
\text { y }\end{array}$ & $\begin{array}{l}\text { Labour } \\
\text { productivity }\end{array}$ \\
\hline $\begin{array}{l}\text { Domestic } \\
\text { assisted }\end{array}$ & -0.8 & -1.4 & -5.0 & -45.2 & -3.5 \\
\hline & $(0.50)$ & $(0.44)$ & $(9.53)^{* *}$ & $\begin{array}{l}(4.75)^{*} \\
*\end{array}$ & $(2.38)^{*}$ \\
\hline Foreign & 7.6 & 6.0 & 3.5 & 13.6 & 32.3 \\
\hline & $(6.99)^{* *}$ & $(2.31)^{*}$ & $(8.42)^{* *}$ & $(2.03)^{*}$ & $(27.75)^{* *}$ \\
\hline Observations & 14024 & 14024 & 14024 & 13968 & 14024 \\
\hline R-squared & 0.15 & 0.06 & 0.23 & 0.06 & 0.38 \\
\hline
\end{tabular}

Note:

(i) Robust t-statistics in parentheses.

(ii) * significant at 5\%; ** significant at $1 \%$.

(iii) The reference group in the regressions consists of domestic establishments in non-assisted areas.

(iv) All regression contains time and four-digit sector dummies.

(v) The wages and capital intensity equations the size of establishments is controlled for.

Table 4 gives some summary statistics for the sample of domestic establishments used in our econometric analysis. Our sample is confined to establishments with complete information for at least three consecutive years ${ }^{7}$.

\footnotetext{
${ }^{7}$ This is to satisfy the minimum requirement for dynamic panel data model estimation.
} 
Table 4

Descriptive statistics of the domestic

establishments in the sample

\begin{tabular}{|l|c|c|c|c|}
\hline & \multicolumn{2}{|l|}{ Assisted Areas } & \multicolumn{2}{l|}{ Non-assisted Areas } \\
\hline & Mean & Std. Dev. & Mean & Std. Dev. \\
\hline Real wages in £'000 & & & & \\
\hline Skilled & 7.44 & 107.33 & 7.49 & 38.53 \\
\hline Unskilled & 4.99 & 84.39 & 5.06 & 27.42 \\
\hline Annual growth rates & & & & \\
\hline Skilled wages & $3.56 \%$ & .012 & $2.91 \%$ & .003 \\
\hline Unskilled wages & $1.11 \%$ & .105 & $2.01 \%$ & .011 \\
\hline Other variables & & & & \\
\hline \% of skilled workers & 29.5 & .007 & 40.3 & .003 \\
\hline employment & 562.31 & 50.03 & 539.39 & 15.24 \\
\hline \# of observations & 317 & & 3482 & \\
\hline
\end{tabular}

\section{Empirical Results}

Table 5 presents the results from the plant level wage equations, employing the simultaneous dynamic panel data framework. For comparison, the single equation estimates are also provided. The global validity of the instrumental variables is confirmed (at 5\% level) by the tests of the overidentifying restrictions reported towards the bottom of the table. This is further reinforced by the absence of a second-order serial correlation in the firstdifferenced models.

Focussing on the simultaneous dynamic panel data estimates, the results suggest that both skilled and unskilled wages exhibit persistence over time as evidenced by the positive coefficients on the lagged dependent variables. The estimates highlight the importance of employing a simultaneous equation estimator, as there are sizable differences in the crosswage coefficients between the two estimators, these differences being highly significant in the case of unskilled workers. Once one allows for simultaneity, the impact of wages in other occupational groups becomes significantly greater than has previously been reported, where 
single equation studies often fail to find this impact, particularly in terms of the effect of skilled wages on unskilled workers.

Establishment size (measured in terms of capital stock) proves to be a significant determinant of pay, consistent with previous empirical findings of a positive size-wage relationship. Also as expected, wage growth is positively correlated with productivity growth, with skilled wages proving to be more sensitive to productivity movements compared with unskilled wages.

Turning to the spillover terms, both types of wages are strongly correlated with the average four-digit industry domestic pay in the region. A $10 \%$ increase in the average skilled (unskilled) wage leads to a 5.2\% (3.2\%) increase in the wages paid at plant level. This is a

\section{Table 5}

\section{Wages spillovers from foreign firms:}

\begin{tabular}{|c|c|c|c|c|}
\hline & \multicolumn{2}{|c|}{ Simultaneous equations } & \multicolumn{2}{|c|}{ Single- equation model } \\
\hline & (1) & (2) & (3) & (4) \\
\hline & $\begin{array}{l}\text { Skilled } \\
\text { Wages }\end{array}$ & $\begin{array}{l}\text { Unskilled } \\
\text { Wages }\end{array}$ & $\begin{array}{l}\text { Skilled } \\
\text { Wages }\end{array}$ & $\begin{array}{l}\text { Unskilled } \\
\text { Wages }\end{array}$ \\
\hline \multirow[t]{2}{*}{ Lagged own wages } & 0.265 & 0.225 & 0.251 & 0.209 \\
\hline & $(6.30)^{* * *}$ & $(3.92)^{* * *}$ & $(6.40)^{* * *}$ & $(5.10) * * *$ \\
\hline \multirow[t]{2}{*}{ Cross wages } & -0.309 & -0.250 & -0.167 & -0.036 \\
\hline & $(2.96) * * *$ & $(4.32)^{* * *}$ & $(4.33) * * *$ & $(1.15)$ \\
\hline \multirow[t]{2}{*}{ Total factor productivity } & 0.205 & 0.136 & 0.178 & 0.106 \\
\hline & $(8.33) * * *$ & $(6.32) * * *$ & $(5.47)^{* * *}$ & $(4.52)^{* * *}$ \\
\hline \multirow[t]{2}{*}{ Capital } & 0.087 & 0.057 & 0.067 & 0.047 \\
\hline & $(4.89) * * *$ & $(3.72) * * *$ & $(5.07) * * *$ & $(3.66)^{* * *}$ \\
\hline \multicolumn{5}{|l|}{ Domestic wages } \\
\hline \multirow[t]{2}{*}{ Four-digit sector own region } & 0.522 & 0.319 & 0.474 & 0.386 \\
\hline & $(10.55)^{* * *}$ & $(8.27)^{* * *}$ & $(7.16) * * *$ & $(8.21)^{* * *}$ \\
\hline \multirow{2}{*}{ Assisted Areas additional effect } & 0.120 & -0.037 & 0.169 & -0.150 \\
\hline & $(1.28)$ & $(0.43)$ & $(1.19)$ & $(1.16)$ \\
\hline \multirow[t]{2}{*}{ Four-digit sector outside region } & -0.003 & -0.022 & 0.042 & 0.013 \\
\hline & $(0.05)$ & $(0.54)$ & $(0.57)$ & $(0.25)$ \\
\hline \multirow[t]{2}{*}{$\begin{array}{l}\text { Assisted Areas } \\
\text { Additional effect }\end{array}$} & 0.917 & 0.423 & 0.819 & 0.074 \\
\hline & $(2.94) * * *$ & $(2.16)^{*}$ & $(2.41)^{*}$ & $(0.19)$ \\
\hline \multirow[t]{2}{*}{ Two-digit sector own region } & 0.143 & 0.220 & 0.165 & 0.420 \\
\hline & $(0.83)$ & $(2.14)^{*}$ & $(0.97)$ & $(4.10) * * *$ \\
\hline \multirow[t]{2}{*}{ Assisted Areas additional effect } & -0.861 & -1.049 & -1.070 & -0.501 \\
\hline & $(1.68)^{*}$ & $(2.28)^{*}$ & $(1.96)^{* *}$ & $(0.57)$ \\
\hline \multicolumn{5}{|l|}{ Foreign wages } \\
\hline \multirow[t]{2}{*}{ Four-digit sector own region } & 0.040 & 0.012 & 0.035 & 0.026 \\
\hline & $(1.87)^{*}$ & $(0.60)$ & $(1.98)^{* *}$ & $(1.26)$ \\
\hline Assisted Areas additional effect & -0.019 & -0.067 & -0.024 & -0.047 \\
\hline
\end{tabular}




\begin{tabular}{|c|c|c|c|c|}
\hline & $(0.31)$ & (1.25) & $(0.46)$ & (1.09) \\
\hline \multirow[t]{2}{*}{ Four-digit sector outside region } & -0.036 & 0.030 & -0.073 & 0.010 \\
\hline & $(1.01)$ & $(1.18)$ & $(2.00)^{* *}$ & $(0.32)$ \\
\hline \multirow[t]{2}{*}{ Assisted Areas additional effect } & 0.073 & -0.123 & 0.193 & -0.120 \\
\hline & $(0.46)$ & $(1.17)$ & $(1.10)$ & $(1.46)$ \\
\hline \multirow[t]{2}{*}{ Two-digit sector own region } & 0.316 & -0.020 & 0.262 & 0.024 \\
\hline & $(2.09)^{* *}$ & $(0.18)$ & $(1.97)^{* *}$ & $(0.20)$ \\
\hline \multirow[t]{2}{*}{ Assisted Areas additional effect } & -0.246 & 0.820 & -0.103 & 0.704 \\
\hline & $(0.57)$ & $(1.85)^{*}$ & $(0.24)$ & $(1.33)$ \\
\hline Time effects jointly significant? & NO & NO & NO & YES \\
\hline Observations & 3783 & & 3799 & 3783 \\
\hline Number of plants & 894 & & 898 & 894 \\
\hline p-value of overidentification statistic & .340 & & .493 & .10 \\
\hline $\begin{array}{l}\text { AR(2) test } \\
\text { p-value }\end{array}$ & & & .720 & .626 \\
\hline
\end{tabular}

substantial outside wage effect, and larger than reported elsewhere. There is also an additional assisted area effect on inter-regional spillovers, which is perhaps not surprising. In areas of high unemployment, wages in neighbouring regions exert strong intra-industry effects. It is well documented that one of the most pressing problems in areas of high unemployment is a shortage of trained people. Thus, workers employed in such locations, particularly in the electronics sector are likely to be difficult to replace. A the more general 2digit level, however, the intra-regional assisted areas term is negative, again not surprising as wages in these areas are lower than average.

It can be noted from Table 5, however, that the corresponding foreign wage does not have discernible effect on the wage of unskilled workers and only a very small impact on skilled wages ${ }^{8}$. There are however significant inter-industry wage spillovers. Two-digit industry skilled foreign wage in the region is found to have a significant influence on plant level wages for skilled workers, a $10 \%$ foreign wages growth leading to $3.1 \%$ skilled wage change at the plant level. But there does not appear to be any additional assisted area effect. By contrast, within-region but inter-industry foreign wages spillovers for unskilled workers are only significant in assisted area. This magnitude this effect is also important with a $10 \%$ 
increase in foreign wages in the same region and 2-digit industry adding $8 \%$ to the unskilled wages in assisted areas. This suggests that where foreign firms (usually in receipt of a subsidy) offer higher levels of unskilled wages, then this can feed through to domestic wage determination.

It is interesting to note that the effects of wages outside the region are generally statistically insignificant, except in the case of skilled wages spillovers from domestic wages in regions with assisted area status. Given that the proportion of skilled workers in assisted areas is significantly lower than the average, this result is consistent with an increase in skilled labour demand elsewhere in the sector biding up wages. Overall, the main conclusion one can draw from Table 5 is that what seems to matter most to plant level wages is the wage dynamics in the domestic rather foreign sector. However to the extent that average sectoral /regional wages are linked to their foreign counterparts, our estimation strategy may underestimate the role of the latter in plant level wage determination.

\section{Further Analysis ${ }^{9}$}

In this part of the paper we extend the analysis in three directions. First, while it is possible that the use of assisted area status as means of distinguishing between types of locations has certain econometric advantages, this may be rather too crude for an analysis of essentially local labour markets. Some areas might have high unemployment rates (e.g. in London), and yet do not have assisted area status. In addition, we therefore employ local unemployment rates as the interaction term ${ }^{10}$. To be more precise, we explore the possibility

\footnotetext{
${ }^{8}$ Elasticity of skilled wages with respect to average foreign wages in the industry region is only .040.

${ }^{9}$ This part of the paper is inspired by the thoughtful comments of the referee to whom we are grateful.

${ }^{10}$ Assisted area status is essentially an exogenous event, influenced by a range of policies, local conditions and political considerations, while unemployment may be seen as being at least in part determined by prevailing wage rates in locality and elsewhere.
} 
of interacting the various wages spillovers parameters with local unemployment rates ${ }^{11}$, to better capture the differential impacts of FDI on wages. Second, we compute the wages effects allowing for distinct productivity spillovers from FDI. Third, we consider other channels through which the rate of globalisation might impact on wage dynamics, namely imports competition, and foreign penetration.

\section{Interactions with local unemployment rates}

The use of a binary dummy variable of assisted area status to allow for heterogeneity in the wages spillovers parameters has the merit of providing easy-to-interpret results. However, it neglects the variation within regions in the same group, and it does not change through time, and as the referee pointed out, it is worth trying alternatives interaction variables such as local unemployment. The results from the simultaneous dynamic panel data models are reported in Table 6. The main results in Columns 1 and 2 of Table 6 are broadly consistent with the those reported in Table 5, but the unemployment interaction term highlights two results. Firstly, the wage spillover for unskilled workers as a result of wages paid by foreign firms the region (at the broader 2-digit level) is more pronounced the higher the local unemployment rate. Secondly, there are also foreign wages related externalities to the wages of skilled workers, but these are independent of local unemployment rates. Overall these results demonstrate that spillovers from foreign wages are intra-regional in nature.

Table 6

Foreign wage spillovers: Further analysis

\begin{tabular}{|c|c|c|c|c|}
\hline & \multicolumn{2}{|c|}{$\begin{array}{c}\text { Interaction with } \\
\text { Local unemployment rate }\end{array}$} & \multicolumn{2}{|c|}{ With foreign competition } \\
\hline & (1) & (2) & (3) & (4) \\
\hline & $\begin{array}{l}\text { Skilled } \\
\text { Wages }\end{array}$ & $\begin{array}{l}\text { Unskilled } \\
\text { Wages }\end{array}$ & $\begin{array}{l}\text { Skilled } \\
\text { Wages }\end{array}$ & $\begin{array}{l}\text { Unskilled } \\
\text { Wages }\end{array}$ \\
\hline Lagged own wages & 0.235 & 0.224 & 0.265 & 0.216 \\
\hline
\end{tabular}

\footnotetext{
${ }^{11}$ The unemployment data is obtained from Office for National Statistics NOMIS service available at http:/parus.dur.ac.uk/.
} 


\begin{tabular}{|c|c|c|c|c|}
\hline & $(5.86) * *$ & $(4.01)^{* *}$ & $(6.48)^{* *}$ & $(3.84)^{* *}$ \\
\hline \multirow[t]{2}{*}{ Cross wages } & -0.368 & -0.286 & -0.337 & -0.262 \\
\hline & $(3.58) * *$ & $(5.15)^{* *}$ & $(3.15)^{* *}$ & $(4.79)^{* *}$ \\
\hline \multirow[t]{2}{*}{ Total factor productivity } & 0.209 & 0.143 & 0.206 & 0.138 \\
\hline & $(8.55) * *$ & $(6.64)^{* *}$ & $(8.25)^{* *}$ & $(6.49)^{* *}$ \\
\hline \multirow[t]{2}{*}{ Capital } & 0.089 & 0.059 & 0.088 & 0.055 \\
\hline & $(4.99)^{* *}$ & $(3.83)^{* *}$ & $(4.93) * *$ & $(3.63)^{* *}$ \\
\hline \multicolumn{5}{|l|}{ Domestic wages } \\
\hline \multirow[t]{2}{*}{ Four-digit sector own region } & 0.502 & 0.309 & 0.434 & 0.182 \\
\hline & $(10.44)^{* *}$ & $(8.10)^{* *}$ & $(4.24)^{* *}$ & $(2.34)^{*}$ \\
\hline \multirow[t]{2}{*}{ Local unemployment rate interaction } & 0.119 & -0.034 & 0.013 & 0.017 \\
\hline & $(1.33)$ & $(0.41)$ & $(1.24)$ & $(1.90)$ \\
\hline \multirow[t]{2}{*}{ Four-digit sector outside region } & -0.001 & -0.023 & -0.139 & 0.076 \\
\hline & $(0.02)$ & $(0.57)$ & $(0.86)$ & $(0.79)$ \\
\hline \multirow[t]{2}{*}{ Local unemployment rate interaction } & 0.894 & 0.404 & 0.022 & -0.011 \\
\hline & $(2.99)^{* *}$ & $(2.13)^{*}$ & $(1.03)$ & $(0.86)$ \\
\hline \multirow[t]{2}{*}{ Two-digit sector own region } & 0.134 & 0.210 & 0.016 & 0.285 \\
\hline & $(0.81)$ & $(2.10)^{*}$ & $(0.04)$ & $(1.05)$ \\
\hline \multirow[t]{2}{*}{ Local unemployment rate interaction } & -0.805 & -1.014 & 0.023 & -0.919 \\
\hline & $(1.63)$ & $(2.26)^{*}$ & $(0.49)$ & $(2.55)^{* *}$ \\
\hline \multicolumn{5}{|l|}{ Foreign wages } \\
\hline \multirow[t]{2}{*}{ Four-digit sector own region } & 0.038 & 0.010 & 0.047 & 0.045 \\
\hline & $(1.86)^{*}$ & $(0.53)$ & $(1.94)^{*}$ & $(1.09)$ \\
\hline \multirow{2}{*}{ Local unemployment rate interaction } & -0.017 & -0.068 & -0.001 & -0.005 \\
\hline & $(0.29)$ & $(1.31)$ & $(0.20)$ & $(1.21)$ \\
\hline \multirow{2}{*}{ Four-digit sector outside region } & -0.035 & 0.030 & -0.086 & 0.088 \\
\hline & $(1.01)$ & $(1.22)$ & $(0.86)$ & $(1.40)$ \\
\hline \multirow[t]{2}{*}{ Local unemployment rate interaction } & 0.075 & -0.112 & 0.006 & -0.010 \\
\hline & $(0.49)$ & $(1.09)$ & $(0.50)$ & $(1.18)$ \\
\hline \multirow[t]{2}{*}{ Two-digit sector own region } & 0.309 & -0.019 & 0.081 & -0.151 \\
\hline & $(2.13)^{*}$ & $(0.17)$ & $(2.03)^{*}$ & $(0.61)$ \\
\hline \multirow[t]{2}{*}{ Local unemployment rate interaction } & -0.028 & 0.790 & -0.063 & 0.222 \\
\hline & $(0.68)$ & $(2.18)^{* *}$ & $(1.32)$ & $(1.96)^{* *}$ \\
\hline \multicolumn{5}{|l|}{ Share of FDI } \\
\hline \multirow[t]{2}{*}{ FDI in Four-digit sector own region } & & & 0.082 & 0.067 \\
\hline & & & $(2.76)^{* * *}$ & $(2.45)^{* * *}$ \\
\hline \multirow[t]{2}{*}{ FDI in Four-digit sector outside region } & & & -0.054 & -0.036 \\
\hline & & & $(1.53)$ & $(1.16)$ \\
\hline \multirow[t]{2}{*}{ FDI in two-digit sector own region } & & & 0.006 & -0.167 \\
\hline & & & $(0.04)$ & $(1.42)$ \\
\hline \multirow[t]{2}{*}{ Log of imports penetration } & & & -0.009 & -0.021 \\
\hline & & & $(0.60)$ & $(2.11)^{* *}$ \\
\hline Time dummies jointly significant? & YES & $\mathrm{NO}$ & YES & NO \\
\hline Observations & 3783 & & 3783 & \\
\hline Number of plants & 894 & & 894 & \\
\hline p-value of overidentification statistic & .233 & & .244 & \\
\hline
\end{tabular}

\section{Wages effects via FDI-induced productivity changes}

FDI can of course influence the wage dynamics of domestic workers via its effect on the productivity of indigenous plants. The extent to which the gains from TFP growth accrue to workers in the form of higher wages can be gauged from the coefficient on the productivity 
term in the wages regressions. The latter suggest that skilled workers have the highest "rentsplitting" parameter, with about a fifth of the productivity growth finding it's way into their wage bill, whereas a $1 \%$ increase in the plant productivity will translate into less than $0.15 \%$ change in the wage of unskilled workers. As pointed out by the referee a large number of papers have studied the impact of FDI on firm level productivity, and these might be used to guide to assess what part of productivity growth is due to FDI. Here we use the estimates reported by Girma and Wakelin (2001) who investigate the productivity impact of regional FDI using the same data set employed in this paper. According their results ${ }^{12}$, a $10 \%$ increase in FDI in the region (at two-digit level) generates a $2.3 \%$ to $5.6 \%$ improvement in the productivity of the average UK-owned plant. Combining this information with our estimates of the rent-splitting parameters, we calculate that a $10 \%$ growth in regional FDI would lead to $0.5 \%$ to $1.1 \%$ additional increases in skilled wages, while its effects on unskilled wages would be between $0.3 \%$ and $0.8 \%$. As such the productivity-induced indirect effects of FDI on domestic wages in the sector are likely to be modest, but biased towards skilled workers.

Is there a foreign investment penetration effect?

In the introduction, we outlined two possible reasons for believing that inward investment may increase wages. Firstly, that the foreign sector tends to pay above average wages, and therefore generates wage spillovers. Secondly however, there is a possibility of an additional labour demand effect. This is illustrated by the fact that when foreign investment penetration is included in the specification, the magnitudes of the inter-industry within region foreign wage spillovers are substantially reduced. However, as can be seen from columns 3 and 4 of Table 6, the regional foreign penetration at the four-digit level have a significant

\footnotetext{
${ }^{12}$ See Table 7 of Girma and Wakelin (2001).
} 
impact on wages, the magnitude of these spillovers being larger for skilled workers. This would appear to suggest that the impact of foreign wages occurs largely through labour demand effects, rather than through workers changing (or threatening to change) jobs by moving from foreign to domestic firms.

\section{The role of imports competition}

A number of empirical papers have focused on testing the hypothesis that imports act to reduce the demand for an industry's output and hence to discipline wage setting. For example Greeenaway et al (2000) report that imports competition in the U.K negatively impacts industry level wages. They also show that trade appears to have disproportionately affected the wages of those at the lower end of the income distribution and therefore served to increase wage inequality. We use our plant level data to further investigate this issue. The results given in Table 6 indicate that imports competition leads to a decline in unskilled workers wages, while it has no discernible effect on the skilled workers' wages in the electronics sectors.

\section{Conclusion}

This paper uses plant level data from the highly "globalised" electronics sector to identify the extent of skilled and unskilled wage spillovers from regional FDI. To our knowledge, this is the first paper that employs a simultaneous dynamic panel data modelling strategy, and both foreign wages and foreign presence variables to this end.

The empirical estimates provide some evidence that wages spillovers are confined to the region FDI takes place, and we uncover some interesting heterogeneity between types of workers. Skilled workers in domestic plants appear to benefit in the form of higher wages from an increase in foreign wages paid at both intra and inter-industry level, inter-industry 
spillovers being more significant. Furthermore the magnitudes of these benefits appear to be uniformly distributed across regions.

By contrast wage externalities to unskilled workers are confined the level of the region and two-digit industry, and these are highly significant and more pronounced in assisted areas. These are regions where workers are typically less mobile, and with high levels of unemployment. It is therefore not surprising that such wage spillovers are geographically limited, but what is perhaps more surprising is that inward investment generates such large (intra-industry, intra-region) wage spillovers, where one would assume there is a large unemployed labour force. One interpretation of this result is that inward investment increases the demand for unskilled workers, but that this largely encourages the "better" unskilled workers to move to higher paid jobs within foreign firms, rather than creating better paid jobs for the hitherto unemployed.

Further, there are additional foreign penetration and FDI-induced productivity related positive effects on domestic wages. Our interpretation of this is that inward investment generates a further increase in demand for skilled labour, with domestic firms then having to pay higher wages to keep key staff. As a result, this effect is more pronounced for skilled than for unskilled workers. The final result derived in this paper concerns the impacts of imports competition and foreign investment penetration on wage rates. Import competition has a negative effect on unskilled wages, while inward FDI has a positive impact on skilled wages, through both technology and labour demand effects. These are interesting findings with the so-called "trade versus technology" debate on the causes of inequality, see for example Machin and Van Reenen (1998) .

Overall, we document evidence of wage spillovers, though largely limited by region and industry, for both skilled and unskilled workers. The impact of inward investment is largely more advantageous to skilled workers rather than the unskilled, while the impact of 
trade is to the detriment of unskilled workers.

\section{References}

Anderson T. and Hsiao C. (1982). 'Formulation and estimation of dynamic models using panel data'. Journal of Econometrics 18, 67-82.

Anselin, L and Florax, R.J.G.M (1995). 'Small sample properties of tests for spatial dependence: Some further results'. In Anselin, L and Florax, R.J.G.M (eds.) New directions in spatial econometrics. Springer, Berlin

Arellano, M and Bond S. (1991). 'Some tests of specification for panel data: Monte Carlo evidence and application to employment equations'. Review of Economics Studies 58 , 277-297.

Baltagi B.H. (1995). Econometric Analysis of Panel Data. John Wiley \& Sons Limited.

Barnes, Matthew and Ralf Martin. 2002. "Business Data Linking: An introduction." Economic Trends, 581, April, pp. 34-41.

Barrell, R. and Pain, N. (1997) 'Foreign direct investment, technological change, and economic growth within Europe.’ Economic Journal, 107, 1770-1786.

Blomström, M, Globerman, S. and Kokko, A. (2001). 'The determinants of host country spillovers from foreign direct investment: review and synthesis of the literature', in N. Pain, ed., Inward Investment, Technological Change and Growth: The Impact of Multinational Corporations on the UK Economy, Palgrave; Basingstok.

Cantwell, J and S. Iammarino (2000) 'Multinational corporations and the location of technological innovation in the UK regions'. Regional Studies, 34(4), 317-332.

Conyon, M., Girma, S., Thompson S. and P.Wright, (2002) 'The productivity and wages effects of foreign acquisitions’. Journal of Industrial Economics. Vol. L, 85-102.

Cornwell, C, Schmidt, P and Wyhowski, D (1992). 'Simultaneous equation and panel data'. Journal of Econometrics 51, 151-181.

Disney, R., Haskel, J. and Heden, Y. (2000) 'Restructuring and productivity growth in UK manufacturing'. University of Nottingham, Centre for Globalisation and Labour Markets, working paper no:2000/13.

Driffield, N. (1996) Global Competition and the Labour Market, Harwood, Reading.

Driffield, N. L. (1999) 'Regional and industry level spillovers from FDI'. presented at the NIESR Conference on inward investment, technological change and growth, British Academy, September $29^{\text {th }}$.

Driffield, N.L. (2001) 'The impact on domestic productivity of inward investment in the UK.' The Manchester School, 69(1), 103-119.

Driffield, N.L. and Taylor, K. (2000) FDI and the labour market: A review of the evidence and policy implications. Oxford Review of Economic Policy, 16(3), 90-103.

Dunning J H (1958) American Investment in British Manufacturing Industry, London: Allen \& Unwin.

Girma, S., Greenaway, D. and Wakelin, K. (2001) 'Who Benefits from Foreign Direct Investment in the UK?' Scottish Journal of Political Economy. 48 (2), 119-33.

Girma, S. and K. Wakelin (2001) 'Regional Underdevelopment: Is FDI the solution: A semiparametric analysis'. GEP Working Paper 2001/14.University of Nottingham. 
Griffith, R., (1999). 'Using the ARD establishment level data to look at foreign ownership and productivity in the UK', Economic Journal, 109, F416-F442.

Greeenaway, D Hine, B and Wright, P (2000) Further evidence on the effect of foreign competition on industry level wages Weltwirtliftshaftliches Archiv, 136 , 41-51.

Holtz-Eakin, D., W.Newey and H.S. Rosen (1988) 'Estimating vector autoregressions with panel data'. Econometrica 56 , 1371-1375.

Latreille, P. and Manning, N. (2000) "Inter-industry and inter-occupational wage spillovers in UK manufacturing”, Oxford Bulletin of Economics and Statistics, 62(1), pp. 83-99.

Le Sage, J.P. (1999) Spatial Econometrics, available at http://www.rri.wvu.edu/regscweb.htm

Lee, K. and Pesaran, M. (1993) 'The role of sectoral interactions in wage determination in the UK economy’. Economic Journal, 103, 21-55.

Machin, S. and Van Reenen, J. (1998) 'Technology and changes in skill structure: Evidence from seven OECD countries'. Quarterly Journal of Economics, 113, 1215-44.

McCormick, B. (1997) 'Regional unemployment and labour mobility in the UK'. European Economic Review, 41, 581-89.

Mcnabb, R. and Whitfield, K. (1998). 'Testing for Segmentation: An Establishment Level Analysis'. Cambridge Journal of Economics, 22(3), 347-65.

Manning, N. (1994) 'Earnings, unemployment and contiguity: Evidence from British counties 19761992’. Scottish Journal of Political Economy, 41(1), 43-68.

Olley, G. S. and Pakes, A., (1996) 'The dynamics of productivity in the telecommunications equipment industry'. Econometrica, 64, 1263-1297.

Oulton, N., (1997) 'The ABI respondents database: A new resource for industrial economics research’. Economic Trends, 528, 46-57.

Pavcnik, N., (2002) 'Trade Liberalization, Exit, and Productivity Improvements: Evidence from Chilean Plants'. The Review of Economic Studies 69, 245-76.

Robinson, P. M. (1988) ‘Root-N consistent semiparametric regression’. Econometrica, 55, 931-954.

Stewart, M.B. (1990). 'Union wage differentials, product market influences and the division of rents'. Economic Journal, 100, 1122 - 1137.

Taylor, J. and Wren, C. (1997) UK regional policy: An evaluation, Regional Studies, 31(9) 832-848. 


\section{Appendix A}

\section{The semiparametric approach to estimating TFP}

This study estimates plant level total factor productivity using the semiparametric approach of Olley and Pakes (1996). As stated in the main text, the major advantage of this approach over more traditional production function estimation techniques is its ability to controls for both selection and endogeneity in a simultaneous fashion. Olley and Pakes (1996) suggest conditioning on a plant's probability of survival to deal with the selection issue, and they address the endogeneity problem by employing investment as a proxy (instrument) for productivity shocks. The reason why investment is correlated with unobserved (to the econometrician) productivity is simple. An establishment with a larger productivity shock this year will invest more than an otherwise similar establishment with a smaller realised productivity shock, because it expects to do better in the future.

In the model by Olley and Pakes (1996), each plant begins period $t$ with the quasifixed input capital, $K_{t}$. It then observes its current productivity, say, $\omega_{t}$, after which it decides whether to stay or exit $\left(\chi_{t}\right)$. Conditional on staying and given output price $p_{t}$, it then chooses the levels of investment $I_{t}$ and variables inputs skilled and unskilled labour and intermediate materials $\left(L_{t}^{s}, L_{t}^{u}, M_{t}\right)$. Using lower cases for log values and indexing establishments by $i$, we write the production function as $y_{i t} \equiv f\left(l_{i t}^{s}, l_{i t}^{u}, m_{i t}, k_{i t}, \omega_{i t}, \varepsilon_{i t}\right)$, where $\mathrm{y}$ is output, the time-varying productivity shock $\omega_{\mathrm{t}}$ is correlated with inputs and $\varepsilon$ is a random error term. For estimation purposes we employ a first-order Taylor approximation and we write the production function as:

$$
y_{i t}=\beta_{0}+\beta_{s} l_{i t}^{s}+\beta_{u} l_{i t}^{u}+\beta_{m} m_{i t}+\beta_{k} k_{i t}+\omega_{i t}+\varepsilon_{i t}
$$

Olley \& Pakes (1996) show that under certain conditions the investment function of a profitmaximising establishment, $i_{i t} \equiv i_{t}\left(k_{i t}, \omega_{i t}\right)$, is strictly increasing in the productivity shock $\omega_{i t}$, so that it can be inverted and one can write $\omega_{i t}=\omega_{t}\left(i_{i t}, k_{i t}\right)$ for some function $\omega_{t}$. Equation (A.1) can then be expressed as

$$
y_{i t}=\beta_{s} l_{i t}^{s}+\beta_{u} l_{i t}^{u}+\beta_{m} m_{i t}+\lambda_{t}\left(i_{i t}, k_{i t}\right)+\varepsilon_{i t}
$$

with

$$
\lambda_{t}\left(i_{i t}, k_{i t}\right)=\beta_{0}+\beta_{k} k_{t}+\theta_{t}\left(i_{i t} \cdot k_{i t}\right) .
$$


. In the first stage, the parameter vector $\beta_{v}=\left(\beta_{s}, \beta_{u}, \beta_{m}\right)^{\prime}$ of the partially linear equation (A.3) can be consistently estimated via semiparametric regression (Robinson, 1988). The estimate of $\beta_{v}$ is then used to purge the contribution of variable inputs in equation (A.1) from the variation in output, i.e.

$$
y_{i t}^{*}=y_{i t}-x_{i t}^{\prime} \beta_{v}=\beta_{0}+\beta_{k i t}+\omega_{i t}+\varepsilon_{i t}
$$

In order to identify the elasticity of capital $\beta_{k}$, it is assumed that productivity follows a first order Markov process ${ }^{13}$, in which case $\omega_{t}$ can be decomposed as $\omega_{i t}=E\left[\omega_{i t} \mid \omega_{i t-1}\right]+u_{i t}$, where $u$ is mean zero innovation term. This allows us to write (A.4) as:

$$
y_{i t}^{*}=\beta_{k} k_{i t}+g\left(\omega_{i t-1}\right)+\varepsilon_{i t}^{*}
$$

where:

$$
g\left(\omega_{i t-1}\right)=\beta_{0} E+\left[\omega_{i t} \mid \omega_{i t-1}\right] \text { and } \varepsilon_{i t}^{*}=\varepsilon_{i t}+u_{i t} .
$$

Now using the first-stage estimate $\hat{\lambda}_{t}$ and the identity expressed in equation (A.3), $g\left(\omega_{i t-1}\right)$ can be rewritten as $g\left(\hat{\lambda}_{i t-1}-\beta_{k} k_{t-1}\right){ }^{14}$ The basic assumption that helps identify $\beta_{k}$ is the one which states that capital is slow to adjust to the innovations, so that conditional on $\omega_{i t-1}, k_{i t}$ is independent of $\varepsilon_{i t}^{*}$. To control for selection, the function $\mathrm{g}($.) can be augmented by the probability of survival function , $\pi_{i t-1}$. In OP this probability depends on the productivity shock $\omega_{i t-1}$ and a threshold productivity level $\omega_{i t}^{*}$. If the establishment's actual productivity is below $\omega_{i t}^{*}$, its future profitability is less than its liquidation value, and this triggers its exit from the market. In this paper we generate the survival probabilities via a probit model using a polynomial series expansion in capital and investment to proxy for productivity. The final estimating equation is then:

$$
y_{i t}^{*}=\beta_{k} k_{i t}+g\left(\hat{\lambda}_{i t-1}-\beta_{k} k_{i t-1} ; \pi_{i t-1}\right)+\varepsilon_{i t}^{*}
$$

In this paper we follow Pavenick (2002) and approximate g(.) by a third order polynomial in $\hat{\lambda}_{i t-1}-\beta_{k} k_{i t-1}$ and $\pi_{i t-1}$.

\footnotetext{
${ }^{13}$ The method easily handles extensions to higher order Markov processes.

${ }^{14}$ The intercept term $\beta_{0}$ is subsumed into the unknown function $g($.)
} 